\title{
Nanostructured titanium dioxide average size from alternative analysis of Scherrer's Equation
}

\section{Tamanho médio das nanopartículas de dióxido de titânio a partir de uma nova abordagem na Equação de Scherrer}

\author{
Francisco Marcone Lima ${ }^{1}$, Felipe Mota Martins ${ }^{1}$, Paulo Herbert França Maia Júnior ${ }^{1}$, \\ Ana Fabíola Leite Almeida ${ }^{1}$, Francisco Nivaldo Aguiar Freire ${ }^{1}$
}

\footnotetext{
${ }^{1}$ Laboratoratório de Filmes Finos e Energias Renováveis, Universidade Federal do Ceará, 60455-760, Fortaleza, CE, Brazil

e-mail: marconeufc@gmail.com; felipemotamartins@hotmail.com; phfmj@yahoo.com.br; anfaleal@yahoo.com; nivaldo@ufc.br
}

\section{RESUMO}

Quantificar o tamanho de materiais em escala nanométrica é um dos desafios a serem superados, uma vez que existem técnicas diferentes. A equação de Scherrer modificada foi usada para estimar o tamanho das partículas de dióxido de titânio em escala nanométrica. Dióxido de titânio com tamanho nominal de nanopartícula de $21 \mathrm{~nm}$ foi usado como padrão para determinar a precisão da equação modificada. A partir dos dados de raios-X, para a amostra sem tratamento térmico foi obtido um valor médio do tamanho das nanopartículas de $20,63 \mathrm{~nm}$. Um tratamento estatístico foi usado para fazer uma correlação entre o valor estimando pela equação de Scherrer modificada e o valor nominal de $21 \mathrm{~nm}$. Um desvio de 0,70 foi encontrado entre o valor calculado e o valor nominal, indicando uma concordância entre os valores. Adicionalmente, a influência da temperatura sobre o tamanho médio das nanopartículas de dióxido de titânio foi pesquisada.

Palavras-chave: Nanomateriais, Equação de Scherrer, Dióxido de Titânio.

\begin{abstract}
The materials sizing in nano-scale is a challenge to be overcome, because the size determined by various methods differ. In order to shed light about the nanomaterials sizing, a modified Scherrer's equation was applied to estimate more accurately the nanostructured titanium dioxide crystal size. The manufactured titanium dioxide-nanostructure powder with nominal average size about $21 \mathrm{~nm}$ was used as the reference standard to determine the accurate of modified equation. From X-ray diffraction data, an average crystal size about 20.63 $\mathrm{nm}$ was achieved for unheated sample. To establish a relation between the result obtained with modified Scherrer's equation and the nominal average crystal size, a statistical treatment and a comparative assessment were performed. The average absolute divergence does not exceed $0.70 \mathrm{~nm}$. The value of crystal size determined from X-ray data was in good agreement with that informed by the supplier. Additionally, the behavior of sample was studied as a function of temperature.
\end{abstract}

Keywords: Nanomaterials, Scherrer's equation, Titanium dioxide.

\section{INTRODUCTION}

In the literature has been reported that the size effects have a strong influence on the properties of nanomaterials. The question is how to define the materials size. One way is using techniques for microstructure characterization with emphasis in the materials sizing. Techniques such as transmission electron microscopy (TEM), atomic force microscopy (AFM), fluorescence correlation spectroscopy (FCS) and others, available for measuring materials sizing are based on different fundamental principles [1]. Among the techniques, an $\mathrm{X}$-ray diffraction (XRD) line profile has been used in study on the nanostructured materials sizing [2-5].

The X-ray diffraction (XRD) for powder samples is well-established and widely used in the field of 
materials characterization to identify the materials that builds its crystalline structure [6]. In addition, the shape of a diffraction peak can be approximated by Gaussian distribution [4,7]:

$$
\beta_{O}^{2}=\beta_{C}^{2}+\beta_{i}^{2}
$$

where $\beta_{\mathrm{o}}$ : measured peak width in radians, $\beta_{\mathrm{C}}$ : width due only to the crystal size D and its microstrain $(\varepsilon)$, and $\beta_{\mathrm{i}}$ : width due only to the instrumental effects.

Therefore from the microstructure characterization with emphasis in the nanomaterials sizing from XRD data analysis, D can be estimate from Scherrer's equation [4,8,9]. Additionally, an apparent size D' can be rough estimate using the equation as described following [8]:

$$
D^{\prime}=\lambda / \beta_{O} \cdot \cos \theta
$$

where $\lambda$ is the radiation wavelength and $\theta$ is the Bragg's angle. The true size D can be obtained from of a correction factor $\mathrm{K}$ as describes follows [8]:

$$
D=K . D^{\prime}
$$

where $\mathrm{K}$ is a dimensionless number known as the Scherrer's constant.

The Scherrer's constant $\mathrm{K}$ can be of the order of unity $[3,8]$, which is regarded that $\mathrm{D}$ is independent of the both size and shape of the material. But, $\mathrm{K}$ can has a deviation from the value of about unity, because it no only depends on the size and shape of the crystal $[3,8,10]$. Moreover, the Scherrer constant K is more often taken as about 0.9 [7,9,11-13], as derived in Scherrer's original paper with $\mathrm{K}=2[2 \ln (2) / \pi] 2[10]$.

The Scherrer's equation negligence the so-called instrumental and microstrain $(\varepsilon)$ effects providing a rough estimate of D value [4]. Thus, in order width $\beta_{\mathrm{O}}$ (Eq.1) needs to be corrected to estimate more accurately the $\mathrm{D}$ value. In relation to the instrumental effect on $\beta_{\mathrm{O}}$, the correction can be made from the instrumental width $\left(\beta_{\mathrm{i}}\right)$ using Caglioti equation [4]. Therefore in relation to the microstrain $(\varepsilon)$, the correction uses the Williamson-Hall plots $[4,14]$. This method supposes that $\mathrm{D}$ and $\varepsilon$ contribute to the broadening in $\beta_{\mathrm{C}}$ with Lorentzian profile as described follows [4].

$$
\beta_{C}=\beta_{D}+\beta_{\varepsilon}
$$

where $\beta_{\mathrm{D}}$ is the width due to change in $\mathrm{D}$ and $\beta_{\varepsilon}$ is the width due to change in $\varepsilon$. Additionally, the value of the width $\beta_{\varepsilon}$ may be calculated using the equation as described follows [4,7].

$$
\beta_{\varepsilon}=4 \cdot \varepsilon \cdot \tan \theta
$$

D values from XRD analysis [2-17] and TEM [1,18,19] have been reported. However, some discrepancies were found between the D values from XRD analysis and other techniques, such as TEM. One possible reason for the discrepancies might be a randomly oriented weak assumption for nanomaterial powder samples with too few particles, for textured nanoparticle ensembles, or for nanoparticle samples characterized by the new nano- and micro-beam X-ray instruments which may sample too few particles [15].

The XRD analysis has been used both structural refinements by the Rietveld method [20] and to determine crystal size [2-17]. To estimate more accurately the D value from XRD analysis, GONÇALVES et al. [4] have exploited the correction in the width $\beta$ o using Caglioti equation, while RAITANO et al. [9], PORKODI AND AROKIAMARY [12], PAL AND CHAUHAN [14] have taken correction factor K as about 0.9 . But, other values for $\mathrm{K}$ can be obtained depending of shapes or crystal size distributions $[8,10]$.

The Scherrer's equation has been used to estimate the $\mathrm{D}$ value of $\mathrm{TiO}_{2}$ nanopowders $[2,12,13,16]$. But, we have not found papers on nanomaterials sizing of $\mathrm{TiO}_{2}$ nanopowders in which report the minimization of the errors caused by instrumental and microstrain effects using correction in the Scherrer's constant K. These accomplishments inspired the study of $\mathrm{TiO}_{2}$ nanomaterial sizing by X-ray diffraction analysis associated with an approach in the correction of $\mathrm{K}$.

\section{EXPERIMENTAL PROCEDURE}

The following procedure allows estimate the crystal size using a modified Scherrer's equation with correction in $\mathrm{K}$ :

a. Differentiating the Bragg law with respect to $\theta$, the following equation can be obtained:

$$
\Delta d / d=-\Delta \theta \cdot \cot \theta
$$

where $\mathrm{d}$ is the interplanar spacing, $\theta$ is the Bragg angle and $\Delta \theta$ is the width of a diffraction peak observed in the angular region near $\theta$.

b. The angular width $(\Delta \theta)$ is defined in radians and it may be described by the following equation:

$$
\Delta \theta=\theta_{1}-\theta_{2}
$$


where $\theta_{1}$ and $\theta_{2}$ are very close to $\theta$ with $\theta_{1}<\theta_{2}$.

c. The width $\beta_{\mathrm{C}}$ is defined as $-\Delta \theta$ and $\varepsilon=\Delta \mathrm{d} / \mathrm{d}$.

d. For $\beta_{\mathrm{i}}=0$ and using a), b), c) and Eqs. 1 to 5, the modified Scherrer's equation can be obtained as describe following.

$$
D=\lambda / 3 \cdot \beta_{O} \cdot \cos \theta
$$

where $\mathrm{K}$ is equal to $1 / 3$.

e. The Scherrer's equation with and without correction in $\mathrm{K}$ was used to calculate the crystal size of $\mathrm{TiO}_{2}$ nanopowders.

The XRD data of the all $\mathrm{TiO}_{2}$ nanopowder samples (Aldrich, purity 99.5\%, 21 nm average size) were obtained from monochromatic radiation diffractometer (Xpert Pro MPD - Panalytical, $\mathrm{Cu}-\mathrm{K} \alpha, \lambda=1.54 \AA, 40$ $\mathrm{Kv}, 45 \mathrm{~mA}$ ) ranging from $10^{\circ}$ to $100^{\circ}(2 \theta)$. The material was used as purchased. The $\mathrm{TiO}_{2}$ samples were annealed at $100-600{ }^{\circ} \mathrm{C}$ for 40 minutes under ambient conditions using a muffle furnace at a heating rate of 7 ${ }^{\circ} \mathrm{C} / \mathrm{min}$.

The phase identification was carried out with Highscore Plus (Panalytical) program. After the identification of phases, each phase corresponding pattern in Inorganic Crystal Structure Database (ICSD) was used for the refinement of structural parameters by the Rietveld refinement using the DBWSTool2.4. The program is free software and it is accessible in http://www.raiosx.ufc.br/site/?page_id $=296$. After refining the data are saved in file in the .OUT format. From the data obtained after Rietveld refinement was estimated value of $\mathrm{D}$ by Scherrer's equation (traditional and modified).

\section{RESULTS}

The Figure 1 shows the XRD data of $\mathrm{TiO}_{2}$ samples for change temperature $600^{\circ} \mathrm{C}$ forward room temperature and the Table 1 shows the crystal size values before thermal treatment. In the Table 2 there is average size of $\mathrm{TiO}_{2}$ nanoparticles before and after thermal treatment and them behavior also showed in Figure 2 by Scherrer's (SC) and modified Scherrer's (MSC). The divergence may be attributed to the instrumental and microstrain effects, which provide a rough estimate of particles size by Scherrer's equation. On the contrary, this does not occur in the modified Scherrer's equation.

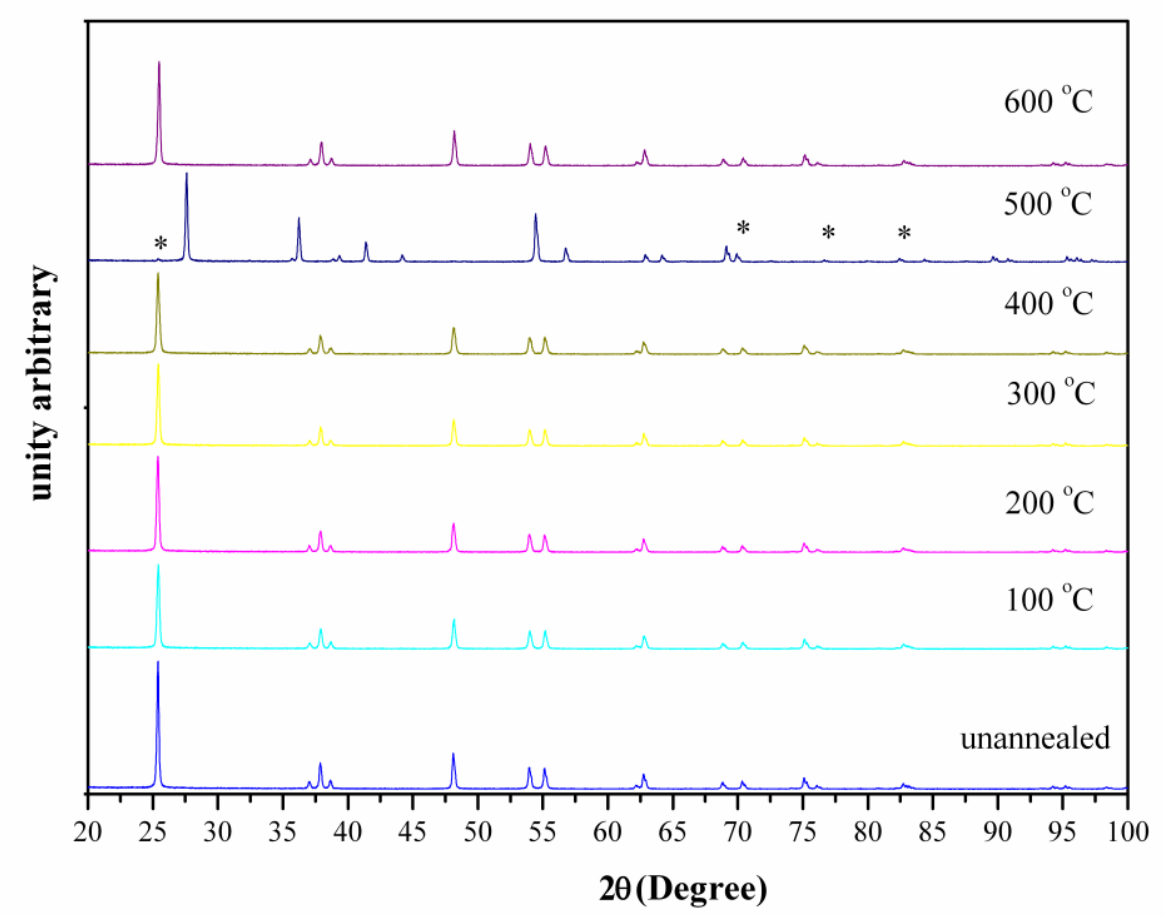

Figure 1: XRD data of anatase $\mathrm{TiO}_{2}$-nanostructured powder samples: unannealed and annealed at 100 up to $600{ }^{\circ} \mathrm{C}$. 
Table 1: Nanostructured $\mathrm{TiO}_{2}$ size powders without thermal treatment calculated by Scherrer's equations.

\begin{tabular}{|c|c|c|c|c|c|c|c|}
\hline $\begin{array}{c}\text { ANGLE } \\
2 \theta \text { (degree) }\end{array}$ & $\begin{array}{c}\text { WIDTH } \\
\beta_{0} \text { (radians) }\end{array}$ & $\begin{array}{l}\text { Scherrer's } \\
\text { equation }\end{array}$ & $\begin{array}{l}\text { Im) } \\
\text { Modified } \\
\text { Scherrer's } \\
\text { equation }\end{array}$ & $\begin{array}{c}\text { ANGLE } \\
2 \theta \text { (degree) }\end{array}$ & $\begin{array}{c}\text { WIDTH } \\
\beta_{o} \text { (radians) }\end{array}$ & $\begin{array}{c}\text { Scherrer's } \\
\text { equation }\end{array}$ & $\begin{array}{l}\text { (nm) } \\
\text { Modified } \\
\text { Scherrer's } \\
\text { equation }\end{array}$ \\
\hline 25.37 & 0.00279 & 56.54 & 18.85 & 76.09 & 0.00311 & 62.96 & 20.99 \\
\hline 37.01 & 0.00279 & 58.18 & 19.39 & 78.71 & 0.00316 & 63.06 & 21.02 \\
\hline 37.86 & 0.00279 & 58.32 & 19.44 & 80.79 & 0.00319 & 63.33 & 21.11 \\
\hline 38.63 & 0.00279 & 58.45 & 19.48 & 82.21 & 0.00323 & 63.31 & 21.10 \\
\hline 48.10 & 0.002827 & 59.66 & 19.89 & 82.72 & 0,00325 & 63.22 & 21.07 \\
\hline 53.95 & 0.00284 & 60.76 & 20.25 & 83.20 & 0.00325 & 63.46 & 21.15 \\
\hline 55.12 & 0.00286 & 60.71 & 20.24 & 92.23 & 0.00349 & 63.66 & 21.22 \\
\hline 62.16 & 0.00291 & 61.71 & 20.57 & 93.29 & 0.00352 & 63.65 & 21.21 \\
\hline 62.74 & 0.00293 & 61.53 & 20.51 & 94.25 & 0.00356 & 63.59 & 21.20 \\
\hline 68.81 & 0.00300 & 62.20 & 20.73 & 95.21 & 0.00358 & 63.85 & 21.28 \\
\hline 70.34 & 0.00301 & 62.41 & 20.80 & 98.37 & 0.00370 & 63.69 & 21.23 \\
\hline 74.11 & 0.00307 & 62.84 & 20.95 & 99.85 & 0.00375 & 63.77 & 21.26 \\
\hline 75.10 & 0.00309 & 62.90 & 20.96 & - & - & - & - \\
\hline
\end{tabular}

Table 2: Average $\mathrm{D}$ and phase of $\mathrm{TiO}_{2}$ as a function of the temperature.

\begin{tabular}{c|c|c|c}
\hline TEMPERATURE $\left({ }^{\circ} \mathbf{C}\right)$ & PHASE & $\begin{array}{c}\text { SCHERRER'S EQUATION } \\
\mathbf{D}(\mathbf{n m})\end{array}$ & $\begin{array}{c}\text { MODIFIED SCHERRER'S EQUATION } \\
\text { D }(\mathbf{n m})\end{array}$ \\
\hline unannealed & anatase $-\mathrm{TiO}_{2}$ & $61.91( \pm 2.11)$ & $20.63( \pm 0.70)$ \\
\hline 100 & anatase $-\mathrm{TiO}_{2}$ & $54.12( \pm 4.80)$ & $18.04( \pm 1.60)$ \\
\hline 200 & anatase $-\mathrm{TiO}_{2}$ & $54.46( \pm 3.50)$ & $18.15( \pm 1.17)$ \\
\hline 300 & anatase $-\mathrm{TiO}_{2}$ & $55.73( \pm 5.22)$ & $16.42( \pm 1.43)$ \\
\hline 400 & anatase $-\mathrm{TiO}_{2}$ & $49.27( \pm 4.29)$ & $17.43( \pm 1.98)$ \\
\hline 500 & anatase $-\mathrm{TiO}_{2}$ & $52.30( \pm 5.93)$ & $23.17( \pm 2.08)$ \\
\hline 600 & rutile $-\mathrm{TiO}_{2}$ & $69.52( \pm 6.25)$ & $18.02( \pm 1.00)$ \\
\hline
\end{tabular}




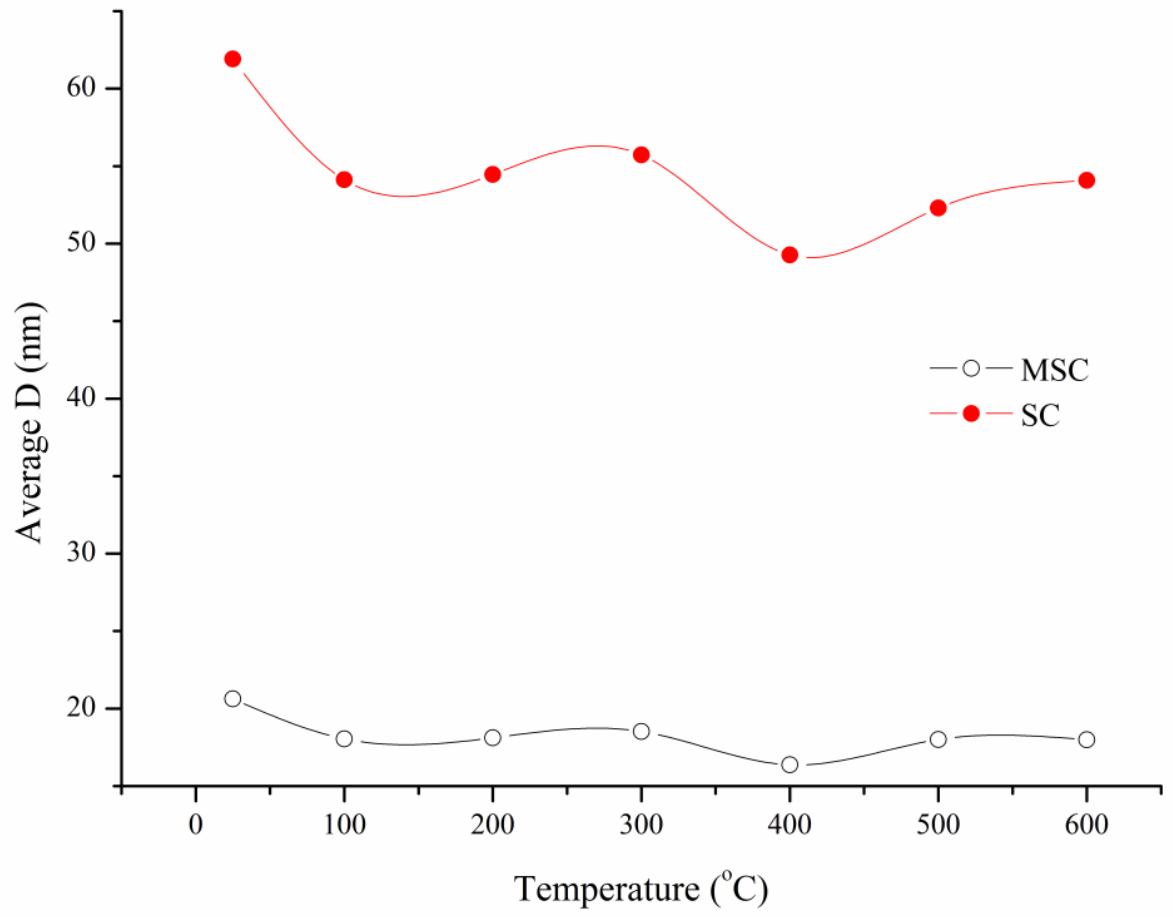

Figure 2: The behavior of $\mathrm{D}$ of $\mathrm{a}-\mathrm{TiO}_{2}$ phase as a function of temperature.

\section{DISCUSSION}

According to Bragg's law, the formation of a diffraction peak should occur when there is a constructive interference of waves emitted from the Bragg's angles $(\theta)$ [6]. The Fig. 1 shows the XRD data of $\mathrm{TiO}_{2}$ samples as a function of temperature. The diffraction peaks of unheated $\mathrm{TiO}_{2}$ sample with nominal average size of $21 \mathrm{~nm}$ matches with the standard patterns of anatase $\mathrm{TiO}_{2}$ (JCPDS card no. 71-1166). The Table 1 shows the crystal size values for sample without thermal treatment. This sample (with nanoparticles average size know) was used as standard to valid the Eq. 8.

The Eq. 6 suggests that as the value of $\theta$ is brought closer to $90^{\circ}$, the fractional error in d-spacing in the crystal as denoted by $\Delta \mathrm{d} / \mathrm{d}$ approaches zero. We should use the diffraction peaks as closer to the value of $2 \theta=180^{\circ}$ as possible to precisely calculate the true value of the d-spacing. In addition, since the measurement of a diffraction peak at $2 \theta=180^{\circ}$ is physically impossible; the value of highly precise d-spacing should be obtained by correction methods of the width $\Delta \theta$.

The width $\Delta \theta$ can be assumed as $\alpha \cdot \cos \theta$ [9] or $\alpha / \sin \theta$ [11], where $\alpha$ is a constant and $\theta$ is the Bragg's angle. In order since $\theta_{1}$ and $\theta_{2}$ are very close to $\theta$ and $\theta_{1}<\theta_{2}$, if is used the angular width $\Delta \theta$ as a measure of a peak width $\left(\beta_{\mathrm{C}}\right)$, i.e, $\beta_{\mathrm{C}}=-\Delta \theta, \varepsilon=\Delta \mathrm{d} / \mathrm{d}$ and $\beta_{\mathrm{i}}=0$ are taken into consideration, the Eq. 8 is obtained.

The nanomaterials sizing has been estimated from a simple Scherrer's equation assuming a spherical shape [16]. From width and D, that K can be: 0.862 - 1.458 (cube shape), 1.078 (sphere shape), $1.457-1.658$ (tetrahedron shape), $1.080-1.430$ (dodecahedron shape) and $0.942-1.452$ (octahedron shape) [3]. But different values for $\mathrm{K}$ can be obtained for different shapes or crystal size distributions [10]. Also, the crystal size effect has hard influence on the XRD line profiles [3]. In this work, the $\mathrm{K}$ value of $1 / 3$ seems has a strong relationship with crystal size distributions effect.

The crystal size shows an obvious inference on the scattering intensity and diffraction angles when the crystal is small enough [3]. Additionally, if fractional error in d-spacing is taken into consideration as $\Delta \mathrm{d} / \mathrm{d}$ (Eq. 6 ), it may infers that to $\Delta \mathrm{d} / \mathrm{d}$ approaches zero, a natural minimization of the errors caused by instrumental effects and microstrain will occur. The Figure 3 shows crystal size as a function of $2 \theta$ for $\mathrm{TiO}_{2}\left(\mathrm{a}-\mathrm{TiO}_{2}\right.$ and $\left.\mathrm{r}-\mathrm{TiO} \mathrm{O}_{2}\right)$ phase determined by modified Scherrer's equation. As consequence, the values of crystal size as function of $2 \theta$ (Table 1) shows that using diffraction peaks with values of $2 \theta$ near to $180^{\circ}$, the best agreement between the nominal crystal size and the sizes calculated from modified Scherrer's equation was obtained. 
$(\mathrm{cc}) \mathrm{EY}$

LIMA, F.M, MARTINS, F.M, MAIA JÚNIOR, P.H.F., et al. revista Matéria, v.23, n.1, 2018.
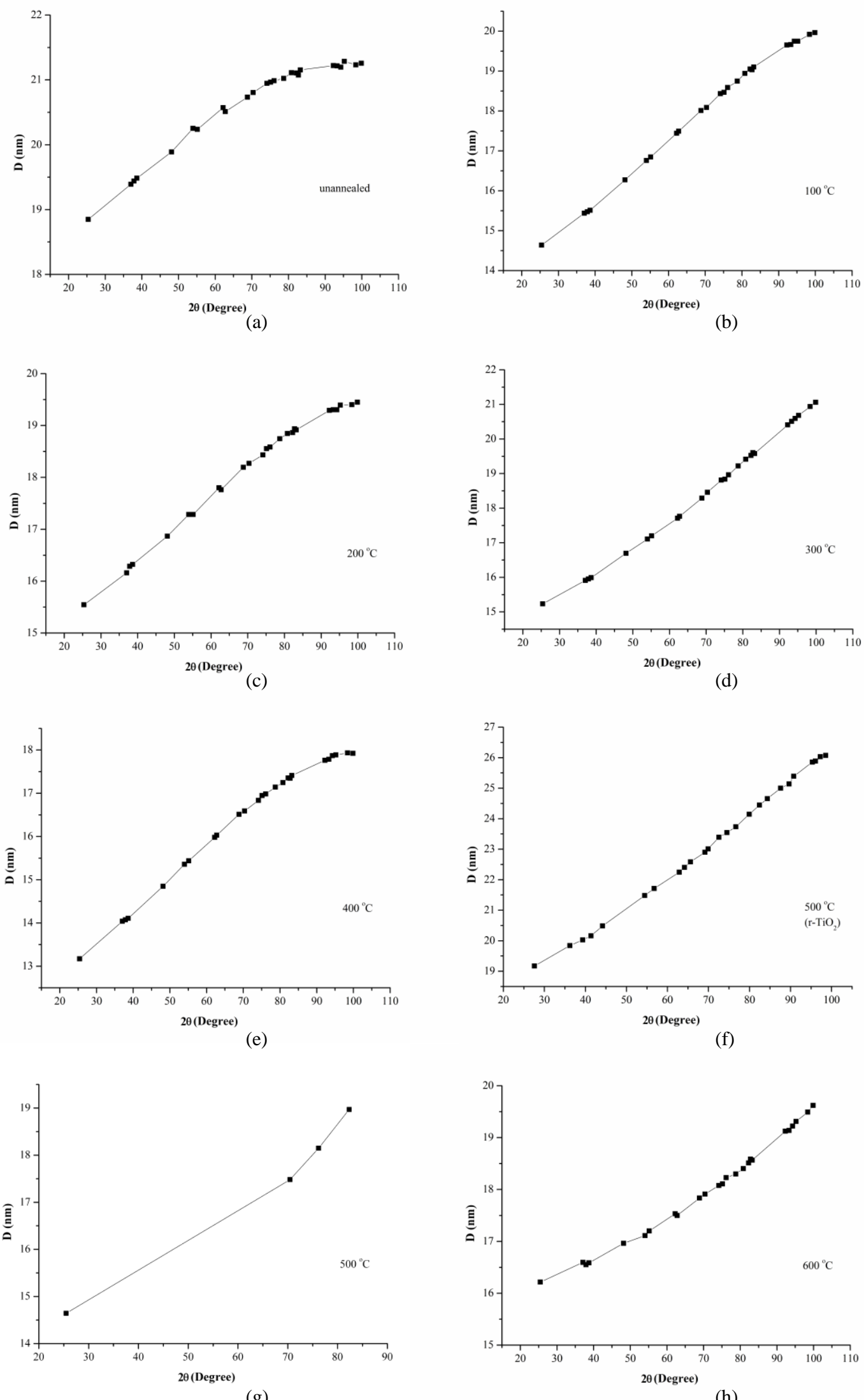

(g)

(h)

Figure 3: The crystal size as a function of $2 \theta$. 
As can be seen from Table 2 data, the average crystal size of $\mathrm{TiO}_{2}$ obtained from the modified Scherrer's equation (Eq. 8) is $20.63 \mathrm{~nm}( \pm 0.70)$, while the average size calculated using the traditional Scherrer's equation is $61.91 \mathrm{~nm}( \pm 2.11)$. It shows that a good agreement between the nominal size of $21 \mathrm{~nm}$ and the size calculated from modified Scherrer's equation was achieved which the average absolute divergence does not exceed $0.70 \mathrm{~nm}$. Thus, the correction in $\mathrm{K}$ allows direct analysis of line broadening without a reference sample, i.e, for condition of $\beta_{\mathrm{i}}=0$.

As mentioned above $[4,14]$, the correction of the broadening in $\beta_{\mathrm{O}}$ due to instrumental and microstrain effects should be possible only using additional equations, what allow us to estimate the $\mathrm{D}$ with best precision. Furthermore, apart from sample-specific contributions to the $\beta_{\mathrm{O}}$, it is important that the $\beta_{\mathrm{i}}$ of the apparatus is accurately determined [10]. Fortunately, Eq. 8 provides the nanomaterials sizing directly from experimental width $\left(\beta_{\mathrm{O}}\right)$ without using additional equations

In the traditional Scherrer's equation there are sources of errors (instrumental factor and microstrain), what provides a rough estimate of particles size [4]. On contrary, the Eq. 8 should be interpreted as the corrected Scherrer's equation, where the correction factor $\mathrm{K}$ equal to $1 / 3$ allows us to estimate the value of $\mathrm{D}$ only due to the chance in D size without the influence of microstrain and instrumental effects.

A peak broadening is calculated based on real diffractometer characteristics such as acquisition geometry, X-ray tube design, primary and secondary optics, specimen size and others [2]. Therefore the results shows that the values for nanomaterial sizing must be estimated from the Eq. 8, because it has the property of eliminate both influence contributions: instrumental effects and microstrain to the broadening in the $\beta_{\mathrm{O}}$. This property seems to arise independently of the path used, possibly due the value of D (Eq. 8) be a net product between the expansion and contraction generated in a stable crystal. Thus, the Equation 8 was used to estimate the average size $\mathrm{D}$ of $\mathrm{TiO}_{2}$ nanoparticles as a function of the temperature (Table 2).

The correction of error in the Scherrer's equation has been reported. MONSHI et al [7] have reported the use of least squares method to mathematically decrease the source of errors in the Scherrer's equation. GONÇALVES et al [4] have exploited the correction for the effects of instrumental broadening using Caglioti equation and separation between size and strain broadening by Williamson-Hall equation. The Table 2 data suggest that from the Equation 8, the error in D-size in the crystal approaches unity. As consequence, in opposition the traditional Scherrer's equation, we may infer that the modified Scherrer's equation (Eq. 8) should be used to estimate more accurately that the values of nanoparticles size.

Additionally, the effect of annealing temperature on the both structure and size of $\mathrm{TiO}_{2}$ was observed. The $\mathrm{TiO}_{2}$ polymorph has three phases: anatase, rutile and bruquita [21-23], and its own intrinsic properties leading to different technological applications in the form of nanoparticles, such as in dye-sensitized solar cells [24-27], lubricant [28], deionization [29], opto-mechanical composite [30] and others. In this experimental work was observed only the anatase- $\mathrm{TiO}_{2}\left(\mathrm{a}-\mathrm{TiO}_{2}\right)$ and rutile- $\mathrm{TiO}_{2}\left(\mathrm{r}-\mathrm{TiO}_{2}\right)$ phases (Figure 1).

According SAMET et al. [16] and SARODE et al. [13], $\mathrm{TiO}_{2}$ calcined at $400{ }^{\circ} \mathrm{C}$ exhibits only diffraction peaks relative to the anatase phase. In this work was observed that the a- $\mathrm{TiO}_{2}$ phase in the samples was determined to be stable from unheated up to $400^{\circ} \mathrm{C}$ and at $600^{\circ} \mathrm{C}$, but at $500{ }^{\circ} \mathrm{C}$ the dominant phase was r$\mathrm{TiO}_{2}$ and some a- $\mathrm{TiO}_{2}$ phase peaks detonated in the Figure 1 as “* *. It appears clearly that, a- $\mathrm{TiO}_{2}$ to $\mathrm{r}-\mathrm{TiO}{ }_{2}$ phase transition takes place for an annealing temperature of $500^{\circ} \mathrm{C}$ and again following the crystallization of a- $\mathrm{TiO}_{2}$ at $600^{\circ} \mathrm{C}$. SUYITNO et al. [24] have been reported the anatase phase be dominant for samples treated up to $600{ }^{\circ} \mathrm{C}$.

From of the combination of the XRD peak analysis and modified Scherrer's equation we infer that have a relationship between the a- $\mathrm{TiO}_{2}$ to $\mathrm{r}-\mathrm{TiO}_{2}$ phase transition and $\mathrm{D}$. The change in size appears (Table 2) to be associated with the phase change, which initially has a reduction of $\mathrm{D}$ stimulated thermally by interparticles mass diffusion without phase shift, however the temperature increase induces a new phase and increase particle. It is obvious that $\mathrm{TiO}_{2}$ nanoparticles size seem has behavior influenced by both temperature and phase change. The Figure 2 shows the $\mathrm{D}$ values for $\mathrm{a}-\mathrm{TiO}_{2}$ as a function of temperature. 


\section{CONCLUSION}

The results show that the modified Scherrer's equation can be used to calculate crystals size directly from measured $\beta$ o located at any $2 \theta$ in the XRD pattern without additional equations for the broadening correction in $\beta$ o. Also, it is possible that, the correction in $\mathrm{K}=1 / 3$ allows eliminating the influence of $\varepsilon$ in estimating $\mathrm{D}$, a fact that cannot be done applying the traditional Scherrer's equation. Furthermore, the temperature and phase transition influence strongly the $\mathrm{TiO}_{2}$ nanoparticles size.

\section{ACKNOWLEDGEMENTS}

The authors thank to the Laboratory of X-rays (proc. nr. 402561/2007-4 MCT/CNPq n ${ }^{\circ} 10 / 2007$ ) from Federal University of Ceará and to FUNCAP, CNPq and CAPES, for supporting this study.

\section{BIBLIOGRAPHY}

[1] DOMINGOS, R.F., BAALOUSHA, M.A., JU-NAM, Y., et al, "Characterizing manufactured nanoparticles in the environment: multimethod determination of particle sizes", Environ. Sci. Technol., v. 43, n. 19, pp. 7277 - 7284, April 2009.

[2] UVAROV, V., POPOV, I., "Metrological characterization of X-ray diffraction methods for determination of crystallite size in nano-scale materials", Mater. Charact., v. 58, n. 10, pp. 883 - 891, October 2007.

[3] ZONGQUAN, L., "Characterization of Different Shaped Nanocrystallites using X-ray Diffraction Line Profiles", Part. Part. Syst. Charact., v. 28, n. 1, pp. 19 - 24, April 2011.

[4] GONÇALVES, N.S., CARVALHO, J.A., LIMA, Z.M. et al., "Size-strain study of NiO nanoparticles by X-ray powder diffraction line broadening", Mater. Lett., v. 72, pp. 36 - 38, April 2012.

[5] JAGRITI, P., PRATIMA, C., "Structural and optical characterization of tin dioxide nanoparticles prepared by a surfactant mediated method", Mater. Charact. v. 60, n. 12, pp. 1512 - 1516, December 2009.

[6] LENG, Y., Materials Characterization Introduction to Microscopic and Spectroscopic Methods, 1 ed., Singapore, John Wiley \& Sons, 2008.

[7] MONSHI, A., FOROUGHI, M.R., MONSHI, M.R., "Modified Scherrer equation to estimate more accurately nano-crystallite size using XRD”, WJNSE, v. 2, n. 3, pp. 154 - 160, September 2012.

[8] LANGFORD, J.I., WILSON, A.J.C., "Seherrer after Sixty Years: A Survey and Some New Results in the Determination of Crystallite Size”, J. Appl. Cryst., v. 11, n. 2, pp. 102 - 113, April 1978.

[9] RAITANO, J.M., KHALID, S., MARINKOVIC, N. et al., "Nano-crystals of cerium-hafnium binary oxide: Their size-dependent structure", J. of All. and Comp., v. 644, pp. 996 - 1002, September 2015.

[10] SMILGIES, D. M. "Scherrer grain-size analysis adapted to grazing-incidence scattering with area detectors", J. Appl. Cryst., v. 42, n. 6, pp. 1030 - 1034, December 2009.

[11] PRAMANICK, A., OMAR, S., NINO, J.C., et al., "Lattice parameter determination using a curved position-sensitive detector in reflection geometry and application to $\mathrm{Sm}_{\mathrm{x} / 2} \mathrm{Nd}_{\mathrm{x} / 2} \mathrm{Ce}_{1-\mathrm{x}} \mathrm{O}_{2-\mathrm{d}}$ ceramics", J. Appl. Cryst., v. 42 , n. 3, pp. 490 - 495, June 2009.

[12] PORKODI, K., AROKIAMARY, S.D. "Synthesis and spectroscopic characterization of nanostructured anatase titania: A photocatalyst", Mater. Charact., v. 58, n. 6, pp. 495 - 503, June 2007.

[13] SARODE, M.T., SHELKE, P.N., GUNJAL, S.D., et al., "Effect of annealing temperature on optical properties of titanium dioxide thin films prepared by sol-gel method", Int. J. of Mod. Phys: Conference Series, v. 6, n. X, pp. 13 - 18, June 2012.

[14] PAL, J., CHAUHAN, P., "Structural and optical characterization of tin dioxide nanoparticles prepared by a surfactant mediated method", Mater. Charact., v. 60, n. 12, pp. 1512 - 1516, December 2009.

[15] ÖZTÜRK, H., "Sampling statistics of diffraction from nanoparticle powder aggregates", J. Appl. Cryst., v. 47, n. 3, pp. 1016 - 1025, June 2014.

[16] SAMETA, L., NASSEUR, J.B., CHTOUROUB, R., et al., "Heat treatment effect on the physical properties of cobalt doped $\mathrm{TiO}_{2}$ sol-gel materials", Mater. Charact., v. 85, pp. 1 - 12, November 2013.

[17] SIDDIQUIA, M.R.H, AL-WASSILA, A.I., AL-OTAIBIB, A.M., et al., "Effects of precursor on the morphology and size of $\mathrm{ZrO}_{2}$ nanoparticles, synthesized by sol-gel method in non-aqueous medium", Mat. Res., v. 15, n. 6, pp. 986 - 989, October 2012.

[18] PYRZ, W.D., BUTTREY, D.J., "Particle size determination using TEM: A discussion of image acquisition and analysis for the novice microscopist", Langmuir, v. 24, n. 20, pp. 11350 - 11360, August 2008. 
[19] MONDINI, S., FERRETTI, A.M., Puglisi, A., et al., "Pebbles and Pebblejuggler: software for accurate, unbiased, and fastmeasurement and analysis of nanoparticle morphology from transmission electron microscopy (TEM) micrographs", Nanoscale, v. 4, n. 17, pp. 5356 - 5372, June 2012.

[20] ZEBALLOS-VELÁSQUEZ, E.L., MELERO, P.C., TRUJILlO, A.L., et al., "Estudio estructural de arcillas de chulucanas por difracción de rayos-X y método de Rietveld ", Matéria, v. 19, n. 2, pp. 159 - 170, June 2014.

[21] SOUSA, R.R.M., DE ARAÚJO, F.O., COSTA, T.H.C., et al., "Thin tin and $\mathrm{TiO}_{2}$ film deposition in glass samples by cathodic cage", Mat. Res., v. 18, n. 2, pp. 347-352, April 2015.

[22] GARCÍA-RUIZA, A., MORALES, A., BOKHIMI, X., "Morphology of rutile and brookite nanocrystallites obtained by X-ray diffraction and Rietveld refinements”, J. of All. and Comp., v. 495, n. 2, pp. 583 - 587 , April 2010.

[23] BAE, E., MURAKAMI, N., OHNO, T., "Exposed crystal surface-controlled $\mathrm{TiO}_{2}$ nanorods having rutile phase from $\mathrm{TiCl}_{3}$ under hydrothermal conditions”, J. Mol. Catal. A: Chem, v. 300, n. 1-2, pp. 72 - 79, March 2009.

[24] SUYITNO, S., SAPUTRA, T.J., SUPRIYANTO, A., et al., "Stability and efficiency of dye-sensitized solar cells based on papaya-leaf dye", Spectrochim. Acta, Part A: Mol. Biomol. Spectrosc., v. 148, pp. 99 104, September 2015.

[25] ZHAO, P., YAO, S., WANG, M., et al., "High-efficiency dye-sensitized solar cells with hierarchical structures titanium dioxide to transfer photogenerated charge", Electrochim. Acta, v. 170, pp. 276 - 283, July 2015.

[26] NARAYAN, M.R., "Review: Dye sensitized solar cells based on natural photosensitizers", Renew. Sust. Energ. Rev., v. 16, n. 1, pp. 208 - 215, January 2012.

[27] CHANG, H., WU, H.M., CHEN, T.L., et al., "Dye-sensitized solar cell using natural dyes extracted from spinach and ipomoea", J. of All. and Comp., v. 495, n. 2, pp. 606 - 610, April 2010.

[28] CHANG, H.; LI, Z.Y., KAO, M.J., et al., "Tribological property of TiO2 nanolubricant on piston and cylinder surfaces", J. of All. and Comp., v. 495, n. 2, pp. 481 - 484, April 2010.

[29] EL-DEEN, A.G., CHOI, J.H., KIM, C.S., et al., " $\mathrm{TiO}_{2}$ nanorod-intercalated reduced graphene oxide as high performance electrode material for membrane capacitive deionization", Desalination, v. 361, pp. 53 - 64, April 2015.

[30] CHANG, W.C., KO, W.C., SHIEH, J., et al., “A photo-sensitive piezoelectric composite material of poly(vinylidene fluoride-trifluoroethylene) and titanium oxide phthalocyanine”, Mater. Chem. Phys., v. 149150, pp. 254 - 260, January 2015. 